\title{
Bax limits adult neural stem cell persistence through caspase and IP3 receptor activation
}

\author{
J Shi ${ }^{1,2}$, LF Parada ${ }^{2}$ and SG Kernie ${ }^{*, 1,2}$ \\ ${ }^{1}$ Department of Pediatrics, UT Southwestern Medical Center, 6000 Harry Hines \\ Blvd, Dallas, TX 75390-9133, USA \\ 2 Center for Developmental Biology and Kent Waldrep Foundation Center for \\ Basic Research on Nerve Growth and Regeneration, UT Southwestern \\ Medical Center, 6000 Harry Hines Blvd, Dallas, TX 75390-9133, USA \\ * Corresponding author: SG Kernie, Department of Pediatrics and Center for \\ Developmental Biology and Kent Waldrep Foundation Center for Basic \\ Research on Nerve Growth and Regeneration, UT Southwestern Medical \\ Center, 6000 Harry Hines Blvd, Dallas, TX 75390-9133, USA. \\ Tel: 214-648-4183; Fax: 214-648-1960; \\ E-mail: Steven.Kernie@utsouthwestern.edu
}

Received 30.11.04; revised 14.4.05; accepted 19.4.05; published online 10.6.05 Edited by S Lipton

\section{Abstract}

Neural stem cells in the mammalian brain persist and are functional well into adulthood. There is, however, little insight into mechanisms that control adult neural stem cell survival. Mice deficient in the proapoptotic molecule Bax exhibit increased numbers of multipotent progenitor cells in the adult subventricular zone. In vitro, these progenitors behave as neural stem cells and utilize Bax and caspase activation to direct cell death. We demonstrate that the predominate mechanism underlying caspase and Bax-mediated adult neural stem cell death lies in the modulation of calcium flux through interaction with the IP3 receptor.

Cell Death and Differentiation (2005) 12, 1601-1612.

doi:10.1038/sj.cdd.4401676; published online 10 June 2005

Keywords: calcium; adult neural stem cells; subventricular zone; apoptosis; caspase-3; IP3 receptor

Abbreviations: CNS, central nervous system; ER, endoplasmic reticulum; His, histamine; IP3R, inositol 1,4,5-triphosphate receptor; SERCA, sarco-endoplasmic reticular calcium ATPase; TG, thapsigargin; WT, wild type

\section{Introduction}

Adult neurogenesis in the central nervous system (CNS) was first recognized more than three decades ago and much is now known about how adult neural stem cells contribute to the olfactory system and parts of the hippocampus. ${ }^{1,2}$ The mitotically active precursor population in the adult brain is a heterogeneous population of cells that include stem cells as defined by their ability to self-renew and undergo multilineage differentiation. ${ }^{3-6}$ In their natural state, these cells divide in the lateral ventricle and subgranular zone of the hippocampus and most eventually undergo apoptosis. ${ }^{7}$ The mechanisms underlying adult neural stem cell apoptosis remain largely unknown despite the fact that the tremendous interest in adult neural stem cell biology is based partly upon their therapeutic potential in brain-injured states. ${ }^{8-13}$

The Bcl-2 family of proteins includes molecules that can promote or repress programmed cell death. ${ }^{14} \mathrm{Bax}$ is a proapoptotic member of this family, and mice deficient in Bax and its related family member Bak have increased numbers of periventricular neural precursor cells, suggesting that Bax and Bak may influence the number of neural stem cells in the brains of adult mice. ${ }^{15,16}$ Bax and Bak initiate programmed cell death by facilitating the release of mitochondrial cytochrome $c$ and activation of the initiator caspase 9 as well as cleavage and activation of the effector caspase $3 .{ }^{17,18}$ Recent data demonstrate that in addition to its direct actions on mitochondria, Bax and Bak also regulate calcium efflux from the endoplasmic reticulum (ER), thus influencing calcium-mediated apoptosis. ${ }^{19}$

The inherent heterogeneity of the adult CNS neural precursor population complicates their in vivo and in vitro study. Here, we investigate the mechanisms behind adult neural stem cell survival in Bax-deficient mice. We demonstrate that Bax deficiency results in an enhanced population of neural precursor cells in the subventricular zone of the lateral ventricles in adult mice. In vitro, these precursor cells retain the properties of adult neural stem cells but are resistant to programmed cell death. These survival-promoting effects permit identification of roles for Bax at the mitochondria and at the ER.

\section{Results}

\section{Bax regulation of adult ventricular neural progenitors}

Bax knockout mice are viable and have essentially normal brain development with the exception of an obvious increase in cellularity adjacent to the lateral ventricle ${ }^{15,16}$ (Figure 1). These supernumerary cells express nestin, a widely used immunologic marker of neural precursor cells (Figure 1b,e). ${ }^{20}$ A subset of the nestin-positive cells also express the neuron specific form of $\beta$-tubulin III (TUJ-1), which is expressed by neural precursors committed to a neuronal fate (Figure 1c, f). ${ }^{21}$ Real-time reverse transciptase PCR (Figure 1g) of dissected SVZ tissue demonstrates that Bax-deficient cells are enriched for nestin mRNA. To definitively determine that the neural precursor cell number was increased in the Baxdeficient SVZ, we crossed Bax-deficient mice to transgenic mice that express GFP under the control of the neural precursor specific form of the nestin promoter. ${ }^{22}$ The adult Bax-deficient SVZ shows a $50 \%$ increase in the number of GFP-expressing cells as assayed by Fluorescence Activated Cell Sorting (FACS) analysis (Figure 1h). Thus, ablation of Bax function causes increased numbers of neural precursors in the adult mouse subventricular zone. 

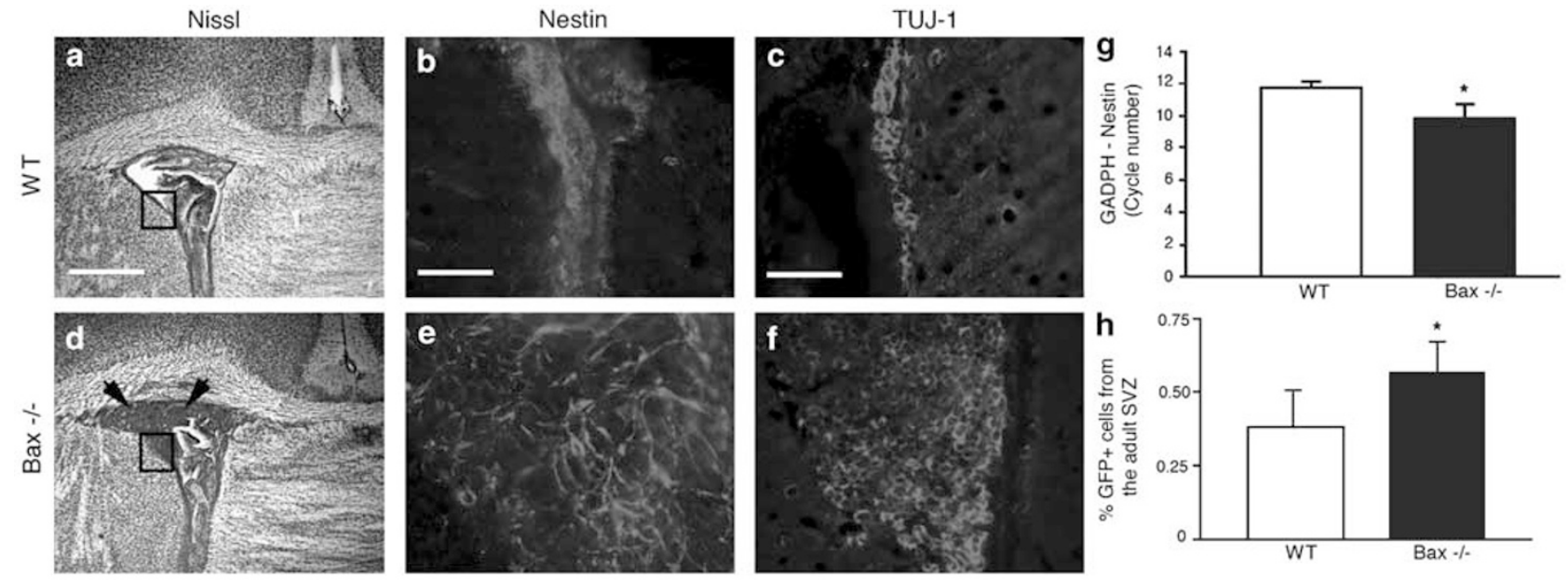

Figure 1 Nissl and immunostained sections depicting the lateral ventricle in wild type (WT) and Bax-/- adult mice. In WT animals, there are no dense collections of small blue cells in the subventricular zone of the lateral ventricle as seen in the Bax-l- mice (a, $\mathbf{d}$ arrows). Higher magnification of similar sections depicting the areas outlined by the black boxes demonstrate that these cells express the undifferentiated neural stem cell marker nestin (b,e), and a subset also express the committed neuronal precursor TUJ-1 (c, f). Messenger RNA was isolated from the SVZ of WT and Bax-I- animals and quantitatively assayed using real time RT-PCR. Panel g demonstrates that nestin mRNA is amplified with fewer cycles in Bax -1 - animals using real-time PCR with nestin specific primers. Bax-l-animals were crossed to GFP-expressing transgenic animals and the dissected SVZ was analyzed using Fluorescent Activated Cell Sorting (FACS). Panel h demonstrates that the Bax-deficient SVZ has increased numbers of GFP-expressing progenitors when compared to WT littermate controls (four animals each group). Error bars are S.E.M. and ${ }^{*} P<0.05$. Scale bars are $500 \mu \mathrm{M}(\mathbf{a})$ and $50 \mu \mathrm{M}(\mathbf{b}, \mathbf{c})$

\section{Precursors in the Bax-deficient subventricular zone demonstrate abnormal proliferation and migration}

Cells born in the subventricular zone typically migrate along the rostral migratory stream to the olfactory bulb where they differentiate into granular and periglomerular neurons. ${ }^{23,24}$ Since there are increased SVZ precursors in the adult Baxdeficient brain, we performed BrdU and Caspase-3 assays to determine whether this increase in vivo was due to enhanced proliferation or decreased death. Figure 2 demonstrates that it is not just the subventricular zone that is increased in Bax deficiency, but the entire rostral migratory stream is thickened (Figure 2a, d). Animals given BrdU and then examined 1 day later show many BrdU + cells in the WT SVZ, but very few in the Bax-deficient SVZ (not shown). In animals given daily BrdU injections for 7 days and then analyzed 3 weeks later, there are few BrdU + cells in the WT subventricular zone $\left(8 \pm 6 \mathrm{cells} / \mathrm{mm}^{2}\right)$, but many in the granular layer of the olfactory bulb $\left(50 \pm 7\right.$ cells $/ \mathrm{mm}^{2}$ ) (Figure $2 \mathrm{~b}, \mathrm{c}$ ). In the Baxdeficient brain, the opposite occurs whereby the thickened SVZ shows many BrdU + cells adjacent to the lateral ventricle $\left(46 \pm 13 \mathrm{cells} / \mathrm{mm}^{2}\right)$, but few have migrated to the olfactory bulb $\left(12 \pm 2\right.$ cells $/ \mathrm{mm}^{2}$ ) (Figure $2 \mathrm{e}, \mathrm{f}$ ). Thus, cells from the Bax-deficient SVZ still actively divide albeit more slowly than in the WT state and few ultimately make it to the olfactory bulb.

To assess whether cells in the olfactory bulb are undergoing cell death, we performed assays for activated caspase-3. We did not observe caspase-3 activation in either the WT or Baxdeficient SVZ (not shown). In the Bax-deficient granular layer of the olfactory bulb, there is no evidence of cleaved caspase3 activity as assessed by immunostaining and Western analysis (Figure 2g, i). This is in contrast to the WT state where there is clear caspase-3-mediated cell death occurring in the granular layer of the olfactory bulb (Figure $2 \mathrm{~h}$, i). It appears that because cells in the olfactory bulb are not dying and therefore in need of replacement in Bax-deficient animals, there is less proliferation and some degree of migratory arrest that occurs in the subventricular zone and rostral migratory stream when compared to the WT state.

\section{Subventricular zone stem cells from adult Bax- deficient mice are more abundant in primary culture}

Stem cells are capable of self-renewal and multilineage differentiation. Accordingly, to assay effects on stem cells, we monitored multilineage neurospheres derived from primary single cells and secondary neurosphere cultures derived from disaggregated primary neurospheres. We refer to other mixed-lineage cells as neural precursors. The behavior of neural stem cells using the neurosphere technique in culture is well characterized. ${ }^{25,26}$ We observed an approximate fivefold increase in the total number of SVZ-derived primary neurospheres in preparations from adult Bax-deficient mice when compared to wild-type (WT) littermates (not shown). Furthermore, neurospheres derived from Bax-deficient mice were significantly larger than WT counterparts (Figure 3a, b). This increase in neurosphere number and size could reflect an increased number of primary stem cells and/or a growth advantage in culture. To examine this, we replated cells from WT and Bax-deficient secondary neurospheres. In total, 10 neurospheres from each culture were dissociated and individual cells were replated at equivalent cell concentrations. The replated cells were monitored for neurosphere number and maximal density (see Methods). The results indicate that secondary Bax-deficient neurospheres achieved 

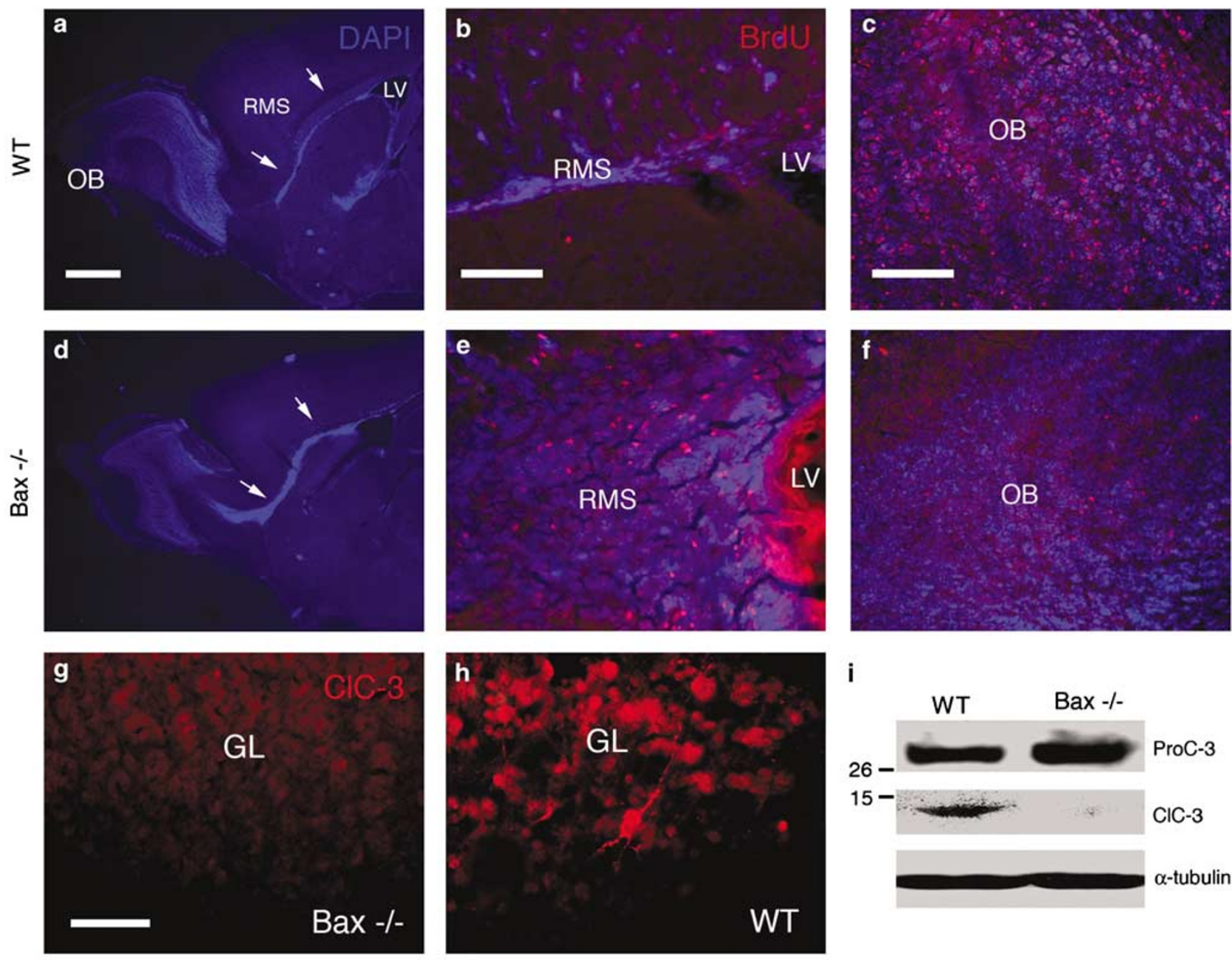

i

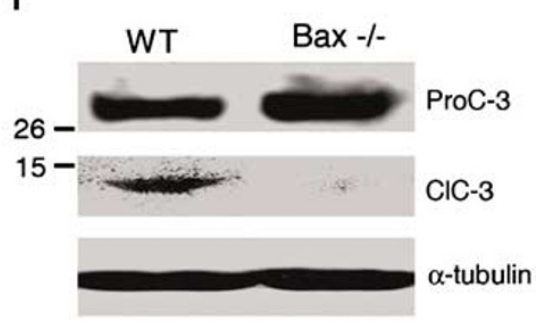

Figure 2 BrdU and cleaved caspase-3 activity in the adult subventricular zone and olfactory bulb. DAPI staining reveals a thickened rostral migratory stream (RMS) in Bax-I- mice when compared to wild type (WT) (a, d, arrows). BrdU given 4 weeks prior to killing shows no labeled cells in the WT RMS but many in the WT olfactory bulb (OB) (b, c). In Bax-l- animals, most BrdU labeled cells are confined to the proximal RMS adjacent to the lateral ventricle (LV) and there are few in the OB (e, f). Whereas procaspase-3 (ProC-3) expression is seen in WT and Bax-l- olfactory bulb (i), cleaved caspase-3 (CIC-3) expression is not apparent by immunohistochemistry or Western analysis in the Bax-deficient granular layer (GL) of the OB (g, i) but is readily apparent in the WT olfactory bulb ( $h$, i). BrdU sections are representative samples from six WT and six Bax - $/$ - animals $(\mathbf{b}, \mathbf{c}, \mathbf{e}, \mathbf{f})$ as are cleaved caspase-3 immunohistochemistry $(\mathbf{g}, \mathbf{h})$ and Western analysis (i). Scale bars are $1 \mathrm{~mm}(\mathbf{a}), 100 \mu \mathrm{M}(\mathbf{b}), 200 \mu \mathrm{M}(\mathbf{c})$, and $50 \mu \mathrm{M}(\mathbf{g})$

maximal density early compared to WT controls (Figure 3c, d). Thus, both in vivo and in vitro, there are more stem/progenitor cells present in Bax-deficient animals.

Upon plating with serum, dissociated neurospheres from both WT and Bax-deficient mice express markers indicative of neurons, astrocytes and oligodendrocytes in the absence of basic fibroblast growth factor (bFGF). Subsets express either the neuronal marker $\beta$-tubulin III and have long projections, acquire an astrocytic morphology along with expression of GFAP, or express the oligodendrocyte-specific marker RIP (Figure $3 e-j$ ). Thus, although increased in number, cultured adult neural stem cells from Bax knockout mice retain the ability to differentiate into neurons and glia.

The overabundance of cultured stem cells observed in Bax knockout adult animals could be due to increased proliferation and/or decreased programmed cell death. We examined neurospheres from WT and control mice for evidence of apoptosis using whole mount immunostaining against activated caspase-3 (Figure 4). This analysis demonstrated active apoptosis within the core of WT neurospheres that was greatly reduced in the Bax-deficient counterparts (Figure 4a-h).

To confirm the attenuation of apoptosis in Bax-deficient stem cells and to obtain quantifiable data, we performed additional assays in dissociated cultures. Primary neurospheres were disaggregated and their constituent cells were allowed to attach and grow on plastic dishes in the absence of bFGF. At 5 days following neurosphere dissociation, cells were assayed for cleaved caspase- 3 activity and $75 \%$ of the WT cells expressed cleaved caspase- 3 compared to $25 \%$ of Bax-deficient cells (Figure 4i-0). We also observed a threefold increase in the number of viable cells in cultures from Bax-deficient mice compared to WT controls 5 days following dissociation (Figure $4 p$ ). Western analysis on 


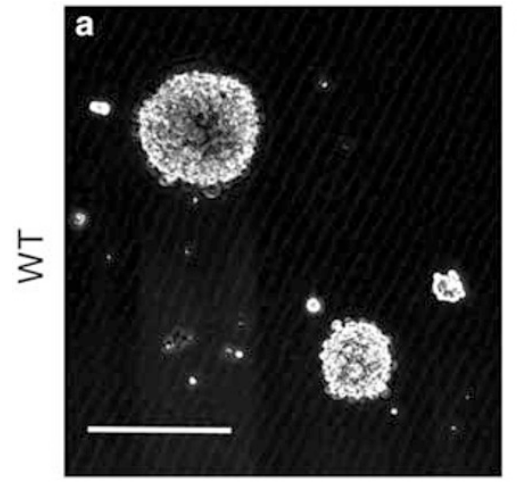

C
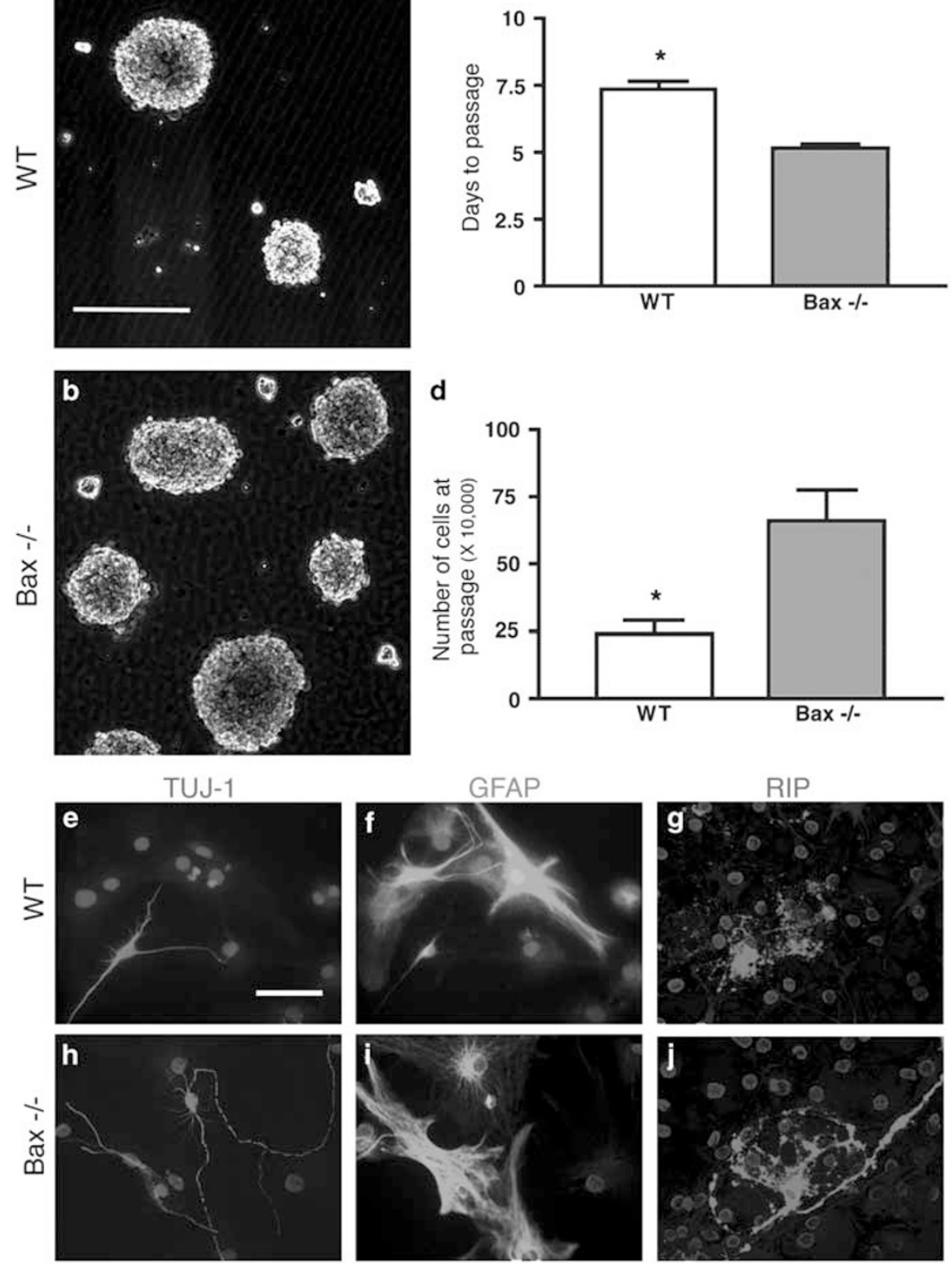

Figure 3 Neurospheres derived from the SVZ of adult wild type (WT) and Bax-I- mice appear larger and more abundant in Bax-deficient adults when initially plated at identical densities $(\mathbf{a}, \mathbf{b})$. When plated from passaged clonal colonies, neurospheres from Bax-deficient animals are passaged sooner (c) and with an almost three-fold increase in cell number (d). Panels e-j show differentiated stem cells in adult WT and Bax-deficient mice. At 10 days following neurosphere dissociation and addition of serum, both groups show differentiated neuronal morphology in cells expressing $\beta$-tubulin III $(\mathbf{e}, \mathbf{h})$, astrocytic morphology in those expressing GFAP (f, i), and oligodendrocytic morphology in cells expressing RIP $(\mathbf{g}, \mathbf{j}) . N=3$ wild type and three Bax deficient animals. Error bars are S.E.M. and ${ }^{\star} P<0.05$. Scale bars are $200 \mu \mathrm{M}$ (a) and $50 \mu \mathrm{M}$ (e)

neurosphere-derived cells confirmed reduced cleaved caspase-3 expression in Bax-deficent cells compared to WT controls (Figure $4 \mathrm{q})$. These data demonstrate that in primary culture, neural progenitors from the Bax knockout mice are more resistant to apoptosis than are WT neural stem cells. In addition, the data are consistent with the model that downregulation of the active form of caspase-3 could account for the phenotype.

We also examined whether Bax-deficient stem cells have increased proliferative properties in vitro. Recent work suggests that in the presence of bFGF, approximately $97 \%$ of cultured neural stem cells are BrdU positive. ${ }^{27}$ We observe that under similar conditions but with fewer passage numbers, $>80 \%$ of both WT and Bax-deficent cells are BrdU positive, and therefore are actively proliferating and there is no difference between WT and Bax deficiency (data not shown).

\section{Caspase-specific inhibitors mimic Bax deficiency}

To examine whether caspase- 3 activity mimics the Bax deficient state in neural precursors, we determined the 

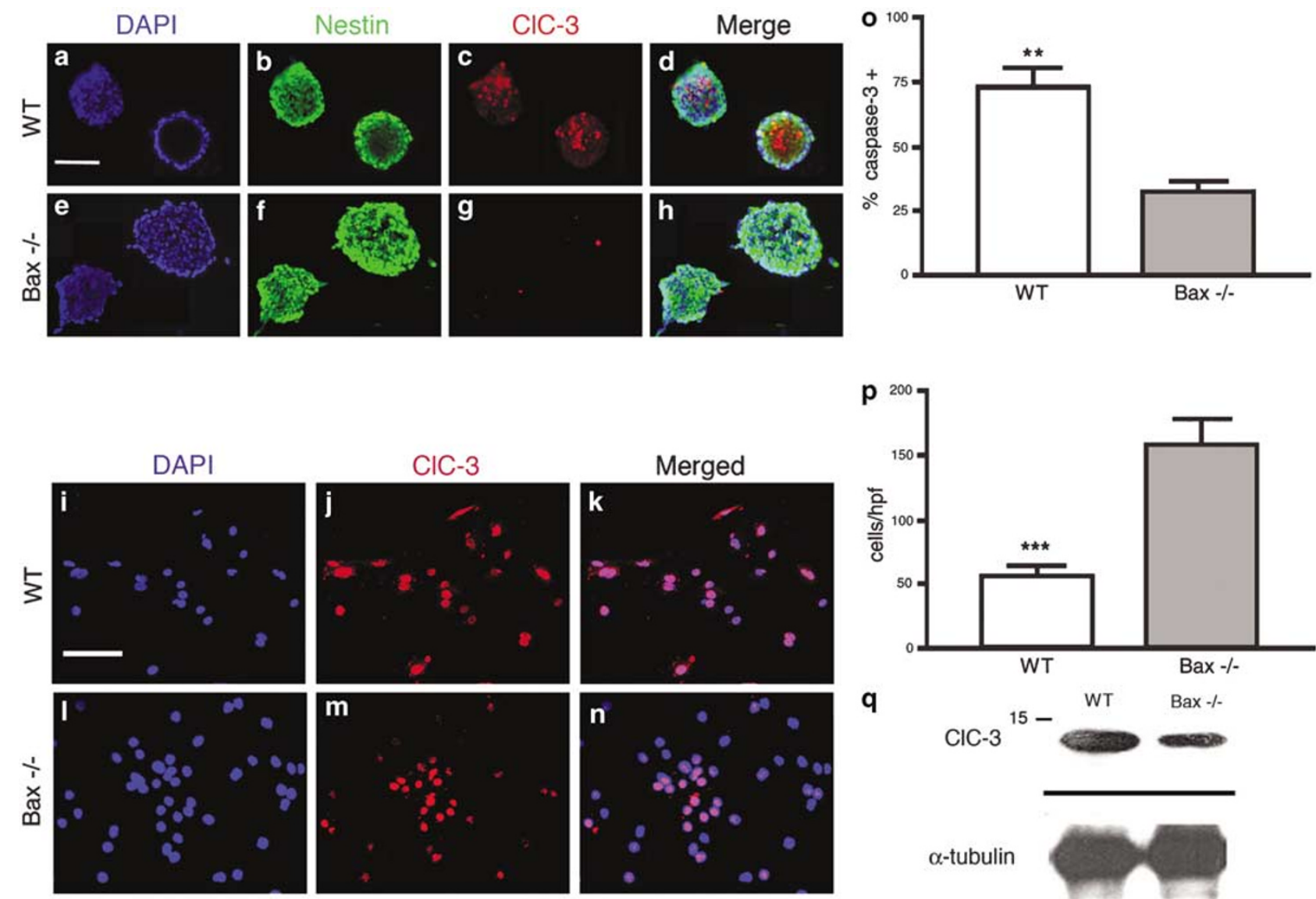

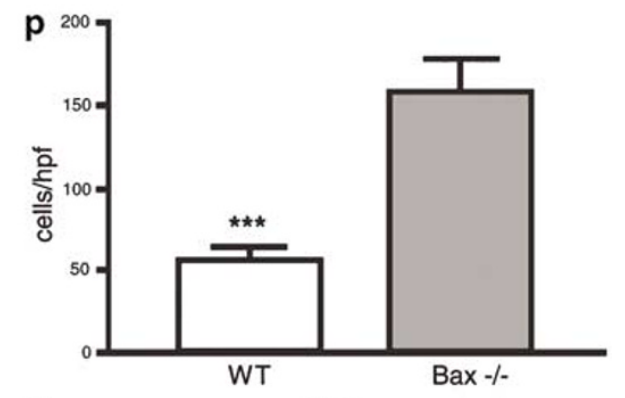

q

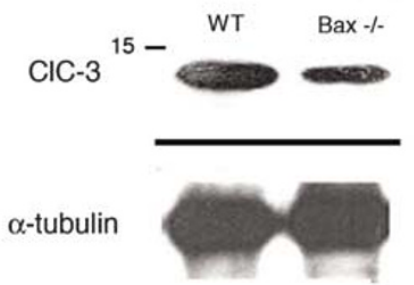

Figure 4 Neurospheres immunostained for nestin and caspase-3 activity. DAPI staining reveals that wild-type (WT) neurospheres show decreased size and decreased cellularity when compared to Bax-I- derived neurospheres (a, e). Neurospheres from the WT and Bax-I-SVZ show uniform nestin expression (b, f) but only WT neurospheres show significant expression of cleaved caspase-3 (CIC-3) $(\mathbf{c}, \mathbf{g})$. Merged images (d, $\mathbf{h}$ ) highlight that the Bax-l- neurospheres are more robust and are undergoing less apparent caspase- 3 mediated cell death. Caspase-3 activity in neurospheres derived from adult WT and Bax $-1-$ SVZ 5 days after dissociation and plating (i-n). Cleaved caspase-3 is more abundant in WT stem cells (i-k) than in Bax-l- cells (I-n). Quantitative counts of cells showing cleaved caspase-3 expression show a three-fold increase for WT in the percentage of cells with caspase-3 activation (o) and more than a three-fold diminution of total cells in WT animals (p). Error bars represent S.E.M. ${ }^{* \star} P<0.01,{ }^{* \star *} P<0.001$. Western analysis of protein extracts from WT and Bax-deficient neurospheres demonstrate decreased expression of activated caspase- 3 in the Bax-deficient state (q). Scale bars are $100 \mu \mathrm{M}$ (a) and $50 \mu \mathrm{M}$ (i)

effects of known caspase inhibitors on cultured adult neural stem cells from WT and Bax-deficient mice. ZVAD. fmk is a nonselective cell permeable inhibitor of caspase-1and -3-like proteases. It has no effect on the initiation of apoptosis, but acts to arrest the apoptotic program before completion. ${ }^{28}$ DEVD is a nonspecific inhibitor of caspases 1 , 3 , and 7, and Ac-IETD-CHO is a procaspase-3 inhibitor that prevents the cleavage of the $32 \mathrm{kDa}$ caspase precursor into p12 and p20 subunits, blocking the formation of active caspase-3. ${ }^{29}$ All three of these caspase inhibitors showed a capacity to protect WT cells in a manner comparable to that of genetic Bax deficiency (Figure 5). Though Bax is known to mediate cell death through activation of caspase-3 in other cell types, it was unclear why the Bax deficient neuronal cell phenotype appeared more restricted to adult progenitors. Since regulators of calcium are known to mediate cell death in a Bax-dependent manner in other cell types, we next sought to determine if similar alterations in calcium might direct death in neural stem cells via caspase-3 activation. ${ }^{19,30,31}$

\section{Bax deficiency attenuates calcium release in neural stem cells}

Recent studies demonstrate that Bcl-2 family members including Bax regulate calcium release from the ER. ${ }^{19,31,32}$ We therefore tested whether Bax deficiency or overexpression alters the release of calcium in cultured adult neural stem cells. Thapsigargin (TG) is an inhibitor of the sarco-endoplasmic reticular calcium ATPase (SERCA) and causes the passive release of calcium from the ER and a subsequent increase in cytosolic calcium. By assaying for dye Fura-2 fluorescence, we found that the TG-induced increase in calcium in Bax-deficient adult neural stem cells was reduced compared to WT cells though the time course of calcium release was similar (Figure 6a). We obtained similar results with histamine that causes an inositol 1,4,5-triphosphate receptor (IP3R)-mediated release of calcium from ER stores (Figure 6b). The opposite occurred with Bax overexpression, whereby both TG and histamine-mediated calcium release was augmented when compared to WT controls (Figure 6d, e). 

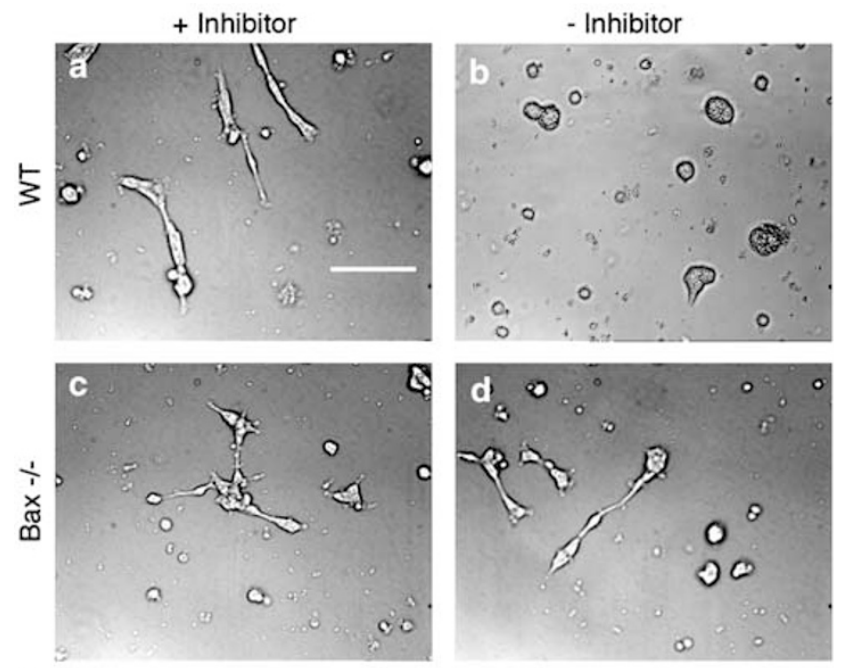

$$
\text { e }
$$

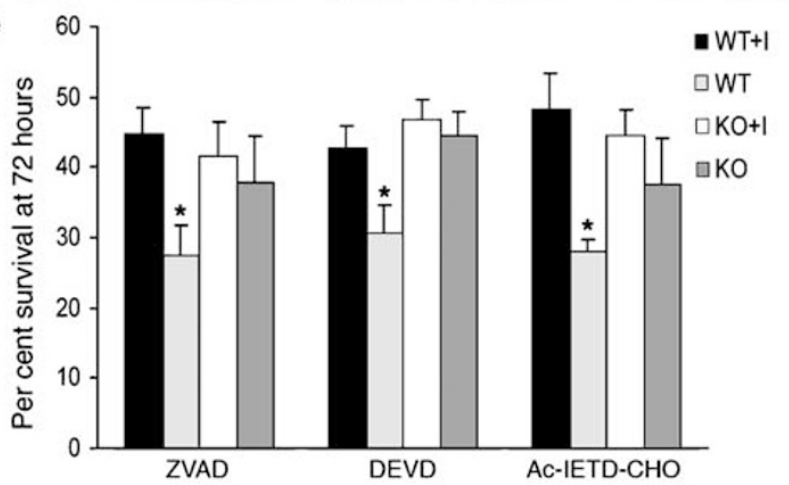

Figure 5 Attentuation of apoptosis in adult neural stem cells via caspase inhibition. ZVAD.fmk inhibits caspases 1 and 3, DEVD inhibits caspases 1, 3, and 7, whereas Ac-IETD-CHO inhibits caspase 3 specifically. At 3 days following plating in limited serum, wild-type (WT) cells treated with ZVAD look morphologically similar to Bax $-1-$ cells with or without ZVAD $(\mathbf{a}, \mathbf{c}, \mathbf{d})$. Wildtype cells without ZVAD appear shrunken and dying (b). Quantitative counts demonstrate that all three caspase inhibitors ZVAD, DEVD, and Ac-IETD-CHO protect WT stem cells from apoptosis though there is no effect on Bax-I- cells (e). Each bar represents the summation of 16 samples repeated three times each. Error bars represent S.E.M. ${ }^{*} P<0.05$. Scale bar is $100 \mu \mathrm{M}$ (a)

Interestingly, whereas TG and histamine-exposed Baxdeficient neurospheres show nearly identical patterns of calcium release, exposed WT neurospheres do not. The cytoplasmic release of calcium in response to histamine showed a $50 \%$ greater peak of $60 \mathrm{nM}$ in TG treated neurospheres and $90 \mathrm{nM}$ following histamine treatment (Figure 6c). Calcium remained elevated in the cytoplasm for $3 \mathrm{~min}$ in the TG-treated neurospheres versus 5 min following histamine treatment (Figure 6a, b). Similarly, in Bax-overexpressing cells, only histamine exposure showed an increase in cytosolic calcium (Figure 6d-f). Thus, Bax-deficient neurospheres show attenuation of both TG and histamine-mediated calcium release, but Bax deficiency had a greater effect on the histamine-mediated IP3 receptor pathway.

Since Bax-mediated ER calcium flux is primarily regulated by both SERCA and the IP3 receptor, we used synthetic small interfering synthetic RNAs to 'knockdown' the expression of each in cultured adult neural stem cells. Reverse transcriptase-PCR from RNA isolated from adult neural precursor cells showed that these synthetic molecules suppress the expression of both SERCA and the IP3 receptor following RNAi transfection (not shown). We then looked at protein expression by Western analysis and demonstrated that using a GFP control RNAi, there is no attenuation of IP3R or SERCA expression in transfected neurospheres (Figure 7a). However, RNAi specific for the IP3R selectively decreases expression of IP3R whereas RNAi specific to SERCA selectively decreases its expression (Figure 7a). Next, we checked whether SERCA and IP3 receptor inhibition attenuates the calcium response to $T G$ and histamine. As shown in Figure $7 \mathrm{~b}-\mathrm{d}$, inhibition of SERCA attenuated the calcium response to TG in cultured WT neurospheres whereas inhibition of the IP3 receptor attenuated the calcium response to histamine. Inhibiting SERCA had no effect on histaminemediated release of calcium and inhibiting the IP3 receptor similarly had no effect on TG-mediated calcium release (not shown).

\section{Inhibition of the IP3 receptor mimics Bax deficiency}

Though we determined that inhibition of both SERCA and the IP3 receptor attenuates calcium flux, it was unclear whether this calcium reduction affects caspase activation or cell survival. Figure 8 demonstrates that inhibition of SERCA caused a slight increase in the activation of caspase-3 in WT cultured adult neural stem cells. Inhibition of the IP3 receptor, like Bax deficiency, decreased the expression of caspase-3 (Figure 8a-c). Similarly, whereas SERCA inhibition led to attenuated cell survival, inhibition of the IP3 receptor improved cell survival (Figure 8d). These data demonstrate that IP3 receptor inhibition phenotypically mimics Bax deficiency by attenuating caspase- 3 expression and activation, and improving adult neural precursor cell survival. Thus, whereas Bax is known to activate cell death both in an ER-dependent and ER-independent manner, we demonstrate that in adult neural stem cells the ER-dependent IP3 receptormediated mechanism is predominant.

\section{Discussion}

Naturally occurring programmed cell death in neural stem cells is fundamentally different than stress-induced apoptosis caused by cell-damaging agents such as UV irradiation or drug exposure. Current models suggest that apoptosis of neural stem cells may occur very soon after cell division leaving one daughter cell committed to cell death because of differential gene expression. ${ }^{33-35}$ While the relative magnitude and precise role of apoptosis in the developing nervous system remain unclear, its importance during early stages of neural development is made apparent from the analysis of mutant mice deficient in components of cell death signaling pathways. In knockout mice for Apaf-1, caspase-9 and caspase-3, the timing of death and the selective enlargement of the ventricular zone suggest that their functions are essential for apoptosis during early development of the CNS. ${ }^{36-40}$ Activation of caspase-3 leads to progenitor cell death, and blocking caspase-3 activation by pan-caspase 

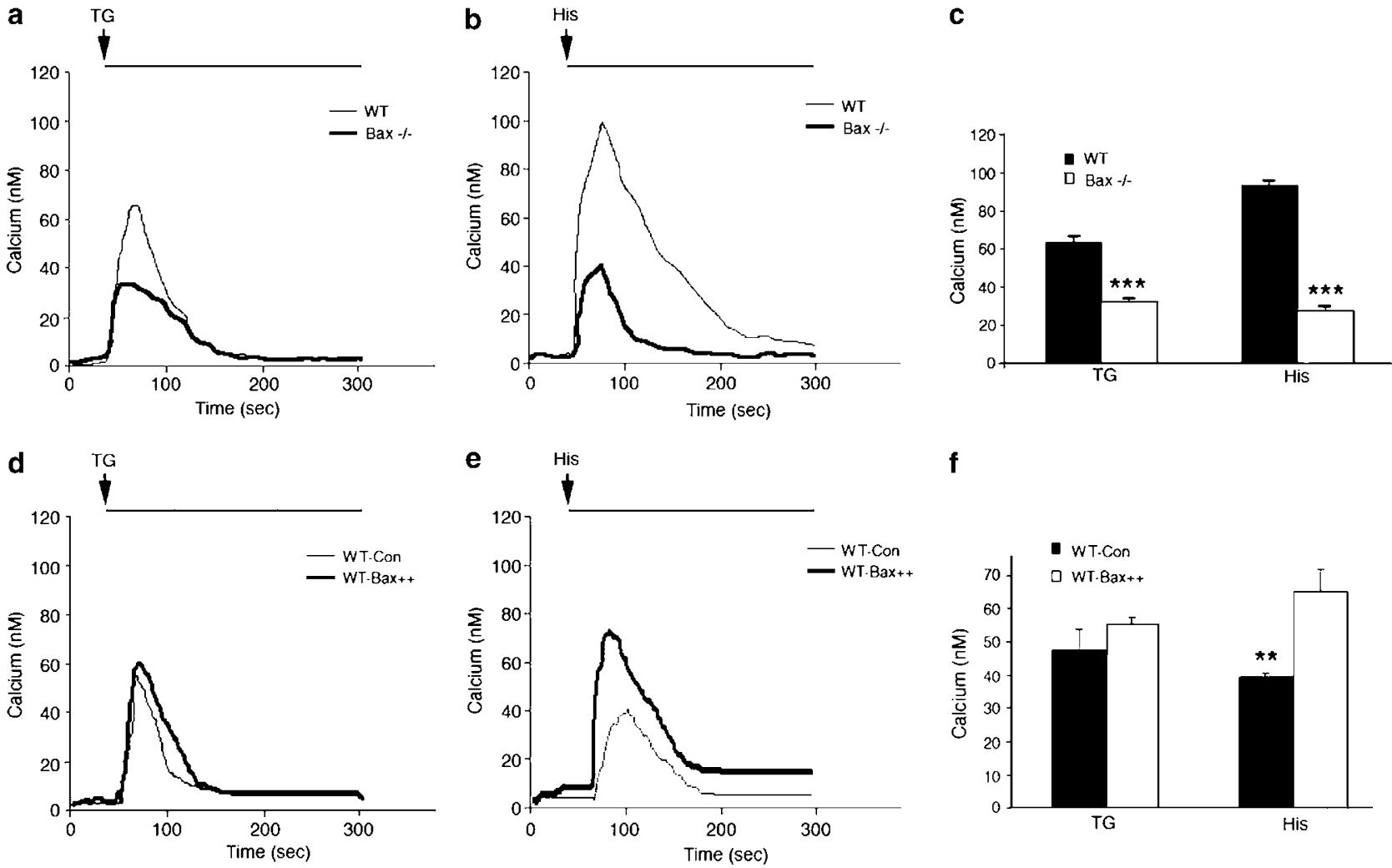

f

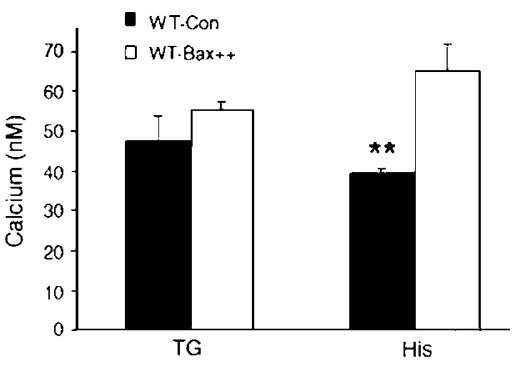

Figure 6 Bax-deficient neurospheres show attenuated $\mathrm{Ca}^{2+}$ release. Cytoplasmic $\mathrm{Ca}^{2+}$ is essentially undetectable at rest in both wild type (WT) and Bax-/neurospheres (a, b). Addition of the SERCA inhibitor thapsigargin (TG) to WT neurospheres stimulates a cytoplasmic $\mathrm{Ca}^{2+}$ spike that diminishes to baseline within 3 min (a). In Bax-1- neurospheres, TG shows a similar time course of cytoplasmic $\mathrm{Ca}^{2+}$ as in the WT but an attenuation of the amount of $\mathrm{Ca}^{2+}$ released (a). Addition of the IP3 receptor agonist histamine (His) in WT neurospheres shows a greater cytoplasmic $\mathrm{Ca}^{2+}$ spike that diminishes to baseline within 5 min (b). Histamine-treated Bax-lneurospheres show much less $\mathrm{Ca}^{2+}$ release into the cytoplasm than WT controls but a similar pattern to that induced by TG exposure (b). This greater difference in $\mathrm{Ca}^{2+}$ release in response to histamine exposure is quantified in panel $\mathrm{c}$ that plots the maximum $\mathrm{Ca}^{2+}$ peak in WT and Bax deficient cells following exposure to TG or His (c). Overexpression of Bax in WT neurospheres has no effect on TG-mediated $\mathrm{Ca}^{2+}$ release (d, f) whereas the $\mathrm{Ca}^{2+}$ peak is enhanced in His-exposed neurospheres $(\mathbf{e}, \mathrm{f})$. Error bars represent S.E.M. of the summation of six independent experiments for both $\mathrm{TG}$ and His for all experiments. ${ }^{* \star} P<0.001$ and ${ }^{* \star} P<0.01$

inhibitors prevents apoptosis, indicating that neural progenitors possess a caspase-dependent apoptotic pathway. ${ }^{41}$ Here, we find that in cultured adult neural stem cells, Bax is a major determinant of apoptosis and acts through modification of IP3 receptor-mediated calcium flux via caspase-3 activation.

Our data indicating the effect of Bax deficiency on the ER and impairment of calcium release to the mitochondria are consistent with recent reports demonstrating the importance of Bax and Bak-regulated calcium release in fibroblasts and thymocytes. ${ }^{19,31}$ Calcium regulation in the ER of cells is an important determinant of cell survival. ${ }^{42}$ SERCA-overexpressing cells increase calcium within the ER and thereby induce apoptosis. ${ }^{43}$ Similarly, TG, an irreversible SERCA inhibitor, interferes with calcium chaperones and induces calcium uptake by the mitochondria and release from the ER, enhancing apoptosis. ${ }^{44} \mathrm{Bcl}-2$ affects calcium handling by increasing the passive leak of the ion across the endoplasmic reticular membrane without changing the calcium uptake capacity of the SERCA pumps. ${ }^{45}$ Whereas $\mathrm{Bcl}-2$ induces a small and long-lasting drop in endoplasmic reticular calcium, TG produces a complete acute calcium depletion activating the capacitative calcium pathway, which conversely is down- regulated in Bcl-2-transfected cells. ${ }^{32}$ In addition to the calcium pathway chaperones such as SERCA, there are other membrane proteins on the ER such as the IP3 receptor that regulate calcium flux and may also sense calcium depletion. $^{42}$

SERCA and the IP3 receptor are candidate mediators of the proapoptotic effects of Bax and Bak by virtue of their roles in the regulation of cellular calcium via the ER. ${ }^{19,31,46}$ While in our studies, Bax deficiency attenuated calcium release in response to TG or histamine, only inhibition of the IP3 receptor protected adult-derived neural precursor cells from cell death. This is consistent with recent data suggesting that Bax and Bak regulate the type I IP3R in mouse embryonic fibroblasts. ${ }^{47}$ While inhibition of the IP3 receptor appears to only impede calcium release from the ER to the mitochondria, blocking SERCA increased cytoplasmic calcium concentrations, thus explaining why SERCA inhibition decreases cell survival. ${ }^{42}$ Although Bax may act upon either calciumregulating protein, its effects on the IP3 receptor appear to dominate as our data suggest that Bax deficiency promotes adult neural stem cell survival by attenuating the transfer of calcium from the ER to the mitochondria. Owing to its effects on the IP3R, we have chosen to focus on the ER as the 
a
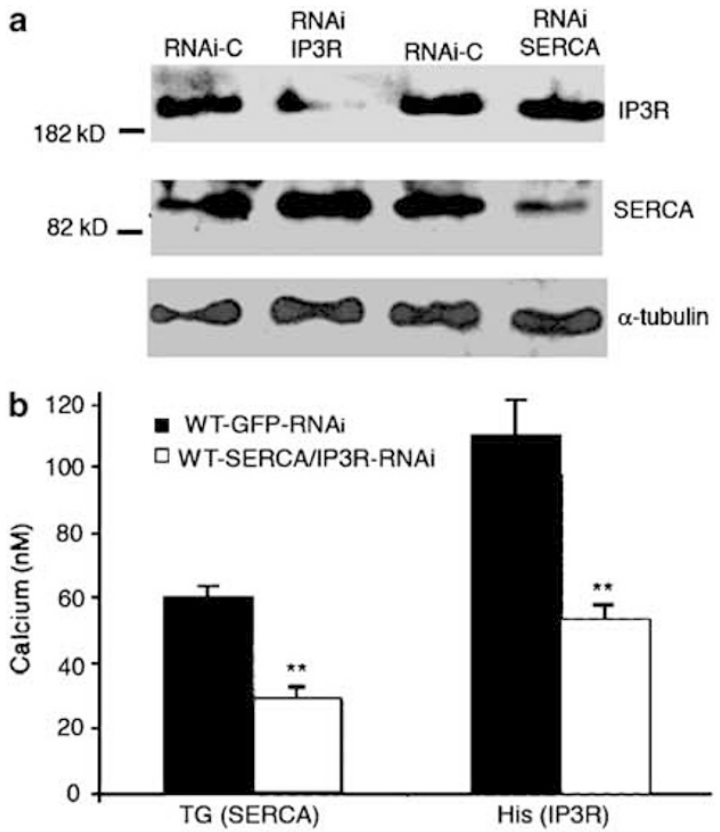

c
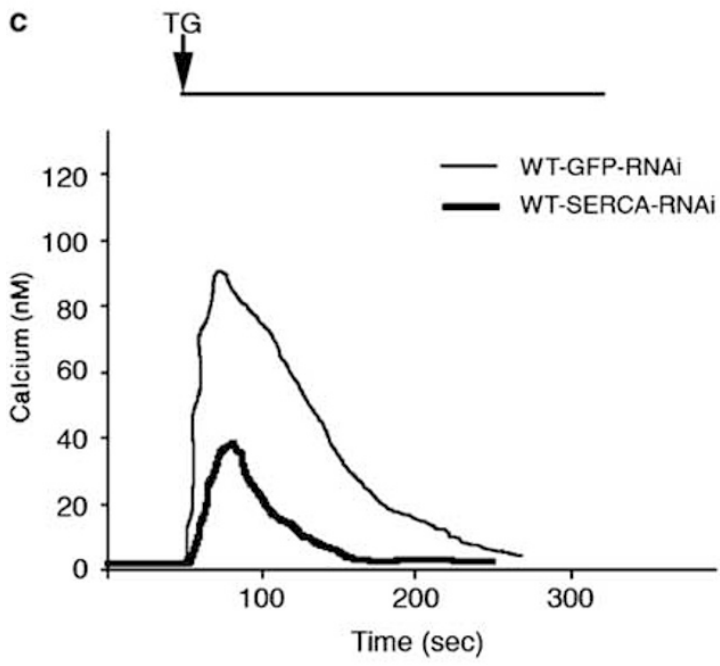

d

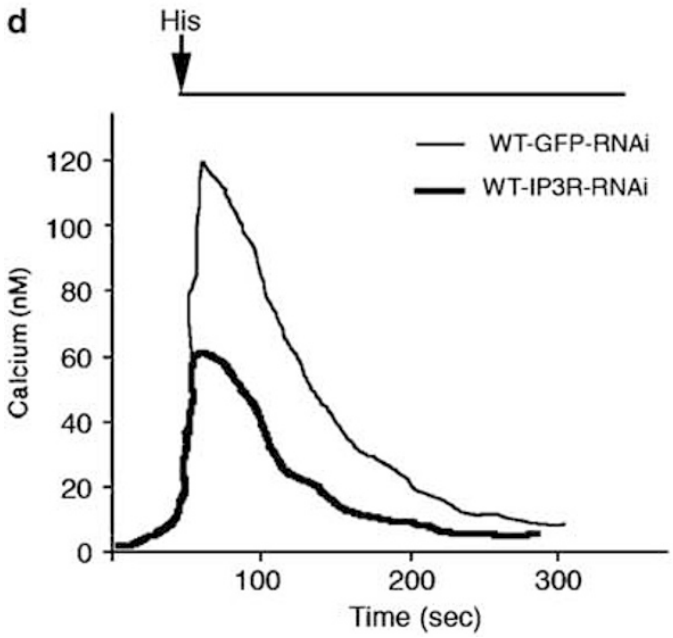

primary site of the proapoptotic effects of Bax in neural stem and precursor cells. However, calcium regulation from the ER is difficult to separate from mitochondrial calcium regulation since the two are so closely approximated physically. ${ }^{48}$ Since Bax also has clear and more extensively studied mitochondrial roles, it remains open to further investigation whether its effects on the IP3R may be secondary to functions localized to the mitochondria.

We demonstrate that in addition to its role in calcium homeostasis, Bax deficiency also attenuates caspase signaling. Caspase-3 cleavage is known to occur downstream of Bax and our data support the model that Bax-regulated calcium driven apoptosis occurs via mitochondrial release of cytochrome $c$. In adult neural stem cells, we observe both decreased caspase- 3 activation as well as decreased procaspase- 3 expression in the Bax-deficient state. Baxdeficient cancer cells also show decreased caspase-3 activation as well as decreased expression of procaspase$3 .{ }^{49}$ By inhibiting the IP3 receptor, our data suggest that the decrease in procaspase-3 expression is regulated by calcium. Thus, the effects of Bax on calcium homeostasis may explain its involvement in discrete apoptotic pathways within cells derived from adult neural stem cells.

It still remains unclear how Bax interacts with the IP3 receptor to modulate calcium signaling to the mitochondria. IP3 receptor levels are not altered by Bax deficiency (not shown), so Bax does not appear to transcriptionally regulate IP3 receptor expression. Interestingly, recent data demonstrate that cytochrome $c$ directly binds to the IP3 receptor to affect calcium-directed apoptosis. ${ }^{50}$ Therefore, the attenuation of calcium flux in Bax deficiency that we observe may be secondary to its effect on early cytochrome $c$ release. In addition, Bax may interact with the IP3R through its localization to mitochondria that then transmit calcium regulatory factors through the closely apposed ER and its IP3 receptors. It is also unclear whether what occurs in adult neurospheres will generalize to other cell systems although recent data suggest that it does. ${ }^{47}$ It is interesting that this phenotype of increased adult neural precursors in Bax deficiency is not apparent in other cells within the brain and it suggests a unique role for Bax within adult-derived neural stem cells.

\section{Materials and Methods}

\section{Generation of mice and in vivo cell counting}

All protocols involving the use of animals were approved by the Institutional Animal Care and Research Advisory Committee (IACRAC) at UT Southwestern Medical Center at Dallas. Bax mice (gift of $S$ Korsmeyer)

Figure 7 RNAi inhibition of SERCA and the IP3 receptor attenuate $\mathrm{Ca}^{2+}$ release into the cytosol. Western analysis of cultured neurospheres transfected with GFP-specific (control), SERCA-specific, or IP3 receptor-specific RNA double-stranded RNA oligos shows specific decreased expression of both SERCA and the IP3 receptor but not attenuation of either in control transfected neurospheres (a). RNAi of SERCA and the IP3 receptor are able to inhibit SERCA and the IP3 receptor by decreasing cytoplasmic $\mathrm{Ca}^{2+}$ release in response to thapsigargin (TG) or histamine (His) (b-d). Panel b represents a summation of four separate experiments for each inhibitor and panels $c$ and $d$ are examples of single experiments that show RNAi-mediated impairment of TG and His-mediated calcium release. ${ }^{* \star} P<0.01$ 
a
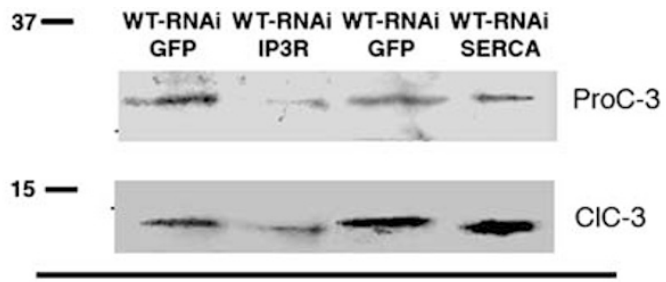

$47-$
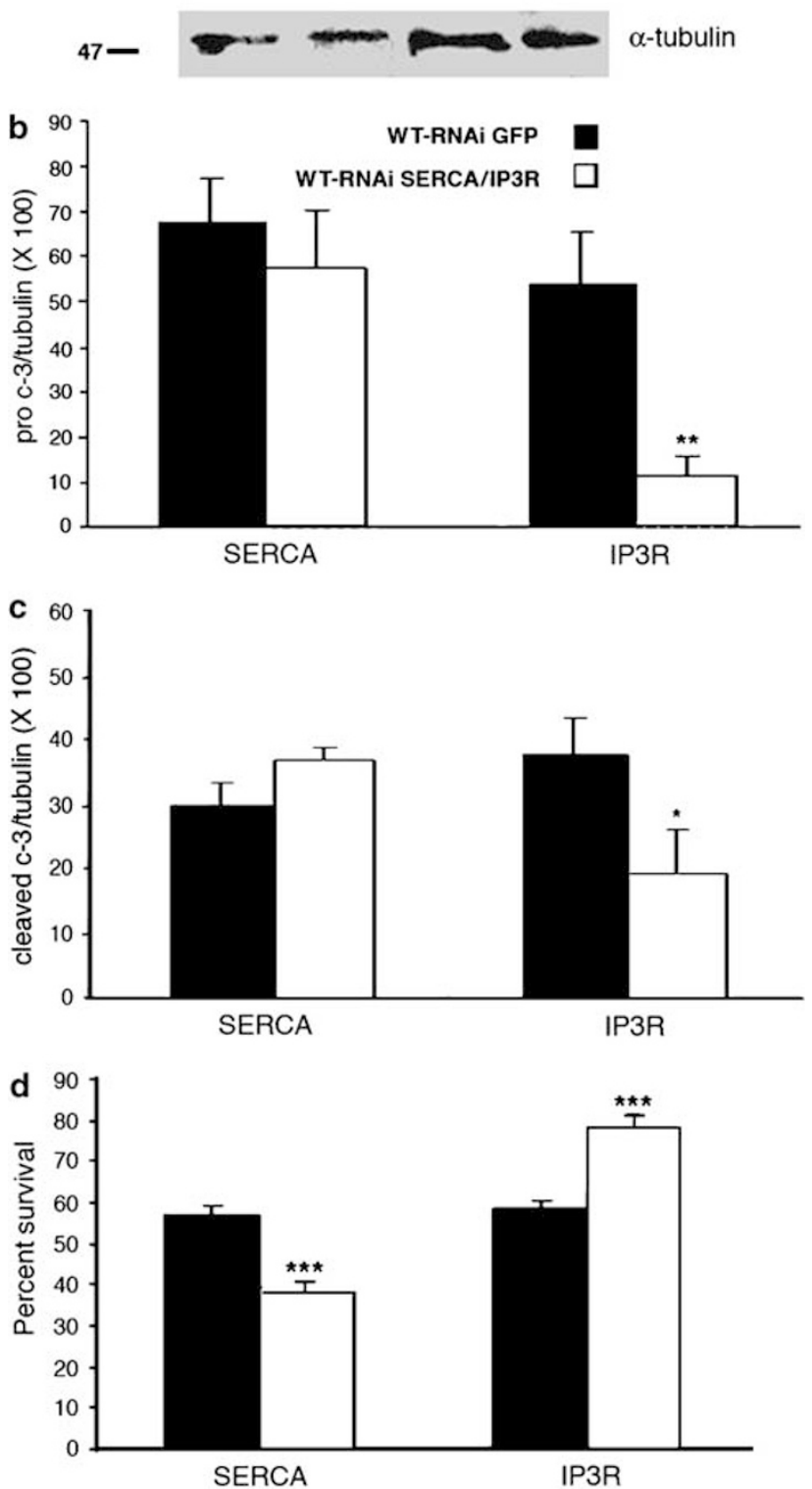

Figure 8 Effects of RNAi inhibition of SERCA and the IP3 receptor on caspase3 expression and cell survival. Western analysis of procaspase-3 (ProC-3) and cleaved caspase-3 (CIC-3) from cultured neurospheres following SERCA and IP3R RNAi transfection demonstrates a decrease in caspase-3 expression in IP3R RNAi-treated cells, whereas caspase-3 expression is unchanged in SERCA RNAi-treated neurospheres (a). Densitometry demonstrates quantitatively that procaspase- 3 is quite decreased when IP3R is downregulated with RNAi (b) and cleaved caspase- 3 is also decreased though both forms of caspase-3 remain the same when SERCA is decreased $(\mathbf{b}, \mathbf{c})$. Whereas treatment of cells from wild type dissociated neurospheres with SERCA RNAi shows decreased survival, treatment with IP3 receptor RNAi shows improved survival (d). Panel d shows the cumulative survival of dissociated neurospheres following transfection with SERCA and IP3R RNAi in four separate experiments for each. ${ }^{* *} P<0.001$, ${ }^{* *} P<0.01$ were generated and genotyped according to previously published protocols. ${ }^{51}$ Bax-deficient mice were crossed to nestin-GFP expressing transgenic mice and maintained as heterozygotes for the nestin-GFP transgene and genotyped also according to a previously published protocol. $^{22}$ BrdU was injected as previously described where six WT and six Bax-deficient mice were injected intraperitoneally with $50 \mu \mathrm{g} / \mathrm{gm}$ bodyweight daily for 7 days and then killed after 3 weeks. ${ }^{12}$ For flow cytometry, the SVZ from four Bax-deficient/nestin-GFP and four littermate controls that only contained the nestin-GFP transgene were analyzed by digesting the SVZ tissue in DMEM with a mixture of $0.1 \%$ neural protease, $0.01 \%$ papain and $0.01 \%$ DNAse (all from Invitrogen) at $37^{\circ} \mathrm{C}$ for $30 \mathrm{~min}$. The cell admixture was then suspended in $0.5 \mathrm{M}$ EDTA, 3\% FBS and $200 \mathrm{U} / \mathrm{ml}$ DNAse I in PBS and the single-cell suspension was processed through an LSR flow cytometer (Pharmingen B-D). GFP cells were counted as a percentage of all cells processed. Histologic cell counts were performed on sagittal sections from each animal (every fifth section from three animals in each group) whereby two $100 \times 100 \mu \mathrm{M}$ areas were counted for each section analyzed. Counts were performed on $16 \mu \mathrm{M}$ cryostat sections and immunostained for anti-BrdU antibody (Pharmingen B-D) and counterstained with DAPI as previously reported. $^{12}$

\section{Primary cell culture}

Neural precursor cells were isolated from the subventricular zone (SVZ) of adult mice. For the experiments listed, there were five mice in the Bax deficient group and six age-matched littermates in the WT group. The lateral ventricular area was isolated by dissection and the tissue digested in DMEM with a mixture of $0.1 \%$ neural protease, $0.01 \%$ papain and $0.01 \%$ DNAse (all from Invitrogen) at $37^{\circ} \mathrm{C}$ for $30 \mathrm{~min}$. Two or three times during digestion, the tissues were gently disrupted through a $1 \mathrm{ml}$ plastic pipette. They were then washed three times with PBS, mechanically dissociated and plated on polyornithine and laminin-coated plates in DMEM/F12 medium containing 10\% FBS. The next day the media was replaced with DMEM/F12, N2 supplement, sodium pyruvate (1 mM), L-glutamine $(2 \mathrm{mM})$ and Heparin $(5 \mu \mathrm{g} / \mathrm{ml})$ and bFGF $(20 \mathrm{ng} / \mathrm{ml})$ (Sigma). The cells were fed every other day with fresh media until formation of neurospheres in 7-10 days. The neurospheres were then transferred to a noncoated dish and passaged after another 7-10 days by mechanical dissociation. Stem cells passaged two or three times were used for quantitative assays shown in Figures 3-5. For neurosphere quantification, at the time of second passage 10 individual neurospheres of equivalent size were taken from SVZ cultures of three WT and three Bax-/- mice. These neurospheres were gently dissociated and plated together in equal densities with approximately 2000 cells per plate (200 cells per neurosphere). The resultant neurospheres were then monitored for growth and cell counts were performed at the time of passage. Both cell, number and days to passage were recorded and statistics performed using a one-tailed Student's $t$-test. For differentiation, the neurospheres were dissociated into single cells and plated on polyornithine coated plates with the above media containing 1\% FBS. For experiments involving calcium handling (Figures 6-8), longer passaged neurospheres from clonal expansion were used at passages 8-10. Clonal cultures were established by dissociating secondary cultures into single-cell suspensions and replating them at low clonal densities $\left(10^{3} \mathrm{cells} / \mathrm{ml}\right)$. Single clusters of dividing cells were transferred to 96 -well plates ( 1 clone/well) using glass pipettes. Cells were monitored for proliferation and reached their maximal proliferation at passages $6-8$ and therefore cells from passages 8-10 were used for experiments. 


\section{Cell counts and statistics}

Equivalent cells (approximately 40000 ) from five Bax knockout and six WT littermates were plated on $18 \times 18 \mathrm{~mm}$ coverslips for Caspase- 3 staining and counting. Each animal's independent culture was plated on two coverslips. Sections were stained with DAPI and Caspase-3 as noted above. Five views were selected at random in the center of each coverslip and pictures of DAPI and Casapse-3 expressing cells were taken and counted by a blinded third party observer. Statistics were carried out using one and two-tailed Student's $t$-test, with significance determined as $P<0.05$.

\section{Caspase assays}

For caspase inhibition experiments, Z-Val-Ala-Asp.flourmethylketone (ZVAD.fmk) (Sigma) was prepared as a $10 \mathrm{mM}$ stock solution in DMSO. Ac-DEVD-cho and Ac-IETD-cho (Sigma) were prepared as stock solutions in water and then added to media with water or DMSO only controls. For the assay, 4000 cells were plated onto 96-well plates, each containing $100 \mu \mathrm{l}$ of $1 \% \mathrm{FBS}$ in media as noted above. Each inhibitor was added at a concentration of $25 \mu \mathrm{M}$. After $72 \mathrm{~h}, 10 \mu \mathrm{l}$ of stock ( $5 \mathrm{mg} / \mathrm{ml}$ in PBS) MTT (3(4,5-dimethylthiazol-2-yl)-2,5-dphenyltetrazoliume bromide) (Sigma) was added to the cultured cells. The reaction was stopped after $2 \mathrm{~h}$ at $37^{\circ} \mathrm{C}$ by removal of media and the addition of $200 \mu$ of acid-isopropanol (100 $\mu \mathrm{l}$ of $0.04 \mathrm{~N} \mathrm{HCl}$ in isopropanol). The plates were left at room temperature for $15 \mathrm{~min}$ in the dark and the absorbance difference at 570-630 nm was measured using a microplate reader. Survival was calculated as (Experiment-Blank)/(Control-Blank) $\times 100 \%$, where the blank is medium + MTT without cells and the control was $5 \% \mathrm{FBS}+$ medium for maximum cell survival. ${ }^{52}$ Statistics were carried out using a two-tailed Student's $t$-test, with significance determined as $P<0.05$.

For the RNAi experiments, GFP, SERCA and IP ${ }_{3}$ R RNAi were prepared as stock solutions in water and then added to neurosphere culture media without bFGF. Each RNA interference molecule was added at a concentration of $20 \mu \mathrm{M}$ with $10 \mu \mathrm{g} / \mathrm{ml}$ Lipofectamine $^{\mathrm{TM}} 2000$ and Lipofectamine $^{\mathrm{TM}}$ only was used as a control. After $10 \mathrm{~h}, 6000$ cells were plated onto 96 -well plates, each containing $100 \mu \mathrm{l}$ of $1 \%$ FBS in media as noted above, then cells were again quantified using the MTT method.

\section{Immunohistochemistry}

Under ketamine/xylazine anesthesia, animals were perfused with $50 \mathrm{ml}$ of PBS followed by $50 \mathrm{ml}$ of $4 \%$ paraformaldehyde in PBS. Brains were dissected and postfixed in $4 \%$ parformaldehyde for $24-48 \mathrm{~h}$. They were mounted in 3\% agarose and then sagittal sections encompassing the entirety of both lateral ventricles were cut into $50 \mu \mathrm{m}$ sections on a vibratome (Leica). Free-floating sections were stored in PBS until immunostaining was performed. Sections were mounted on plus slides (Anapath), allowed to air dry then washed with PBS. For nestin, cleaved caspase-3, and TUJ-1 immunostaining, sections were mounted and dried then washed in PBS as described above. Slides were permeablized with $0.3 \%$ Triton X-100 followed by PBS wash then blocked with $3 \%$ horse serum for $1 \mathrm{~h}$ and incubated overnight with mouse anti-Nestin 1:100 (Pharmingen B-D), Cleaved caspase-3 (Cell Signaling Technology Inc.), and mouse anti-TUJ-1 1:500 (Babco). Secondary antibody was again Cy3 goat anti-mouse as described above. Slides were coverslipped with immuno-mount (Shandon) and visualized with an Olympus BX-50 microscope. Images were obtained with a Photometrics CoolSnap fX CCD camera and analyzed using Metamorph software.
For primary neurosphere and neuronal cultures, we used the following primary antibodies and dilutions: GFAP ( $1: 2000$; rabbit; DAKO), cleavedCaspase-3 (1 : 100; rabbit; Cell Signaling Technology Inc.), TUJ-1 (1:500; mouse; Babco), RIP (1:50, University of lowa Developmental Studies Hybridoma Bank) and DAPI (1:2000; 4'-6-Diamidino-2-phenylindole$2 \mathrm{HCl}$ '). Secondary antibodies were all from Jackson Immunoresearch and used at concentrations of $1: 200$ and included Cy3 goat anti-mouse and anti-rabbit and Cy2 goat anti-rabbit. The stem cells were plated on coverslips with $1 \%$ FBS in DMEM/F12, N2 supplement, sodium pyruvate (1 $\mathrm{mM})$, L-glutamine $(2 \mathrm{mM})$ and heparin $(5 \mu \mathrm{g} / \mathrm{ml})$. The coverslips were coated with polyornithine and laminin (all culture reagents from Invitrogen). For BrdU staining, cells were incubated with $10 \mu \mathrm{g} / \mathrm{ml} \mathrm{BrdU} \mathrm{(Sigma)} \mathrm{for}$ $40 \mathrm{~h}$ then the media was changed. We performed Caspase 3+ DAPI and at 5 days, and TUJ-1 + GFAP + RIP + DAPI at 10 days. Independently prepared, at least three samples of each culture condition were examined. Briefly, cells were fixed with $4 \%$ pfa in PBS for 30 min, rinsed three times with PBS, and treated as follows: cells were first preincubated with PBS containing $0.3 \%$ Triton X-100 (PBST) for $30 \mathrm{~min}$, then incubated with PBST containing $10 \%$ preimmune goat or donkey serum for $1 \mathrm{~h}$. The cells were then incubated with primary antibodies in PBST-DS or PBST-GS overnight at $4^{\circ} \mathrm{C}$. After three washes with PBST, the cells were incubated for $1 \mathrm{~h}$ with secondary antibodies. The cells were then washed three times with PBST. The coverslips were transferred onto glass slides bearing mounting media (Shandon) and visualized with an Olympus BX-50 microscope. Images were obtained with a Photometrics CoolSnap fx CCD camera and analyzed using Metamorph software.

For neurosphere immunostaining, at time of passage small neurospheres were transferred to 12-well plates and allowed to grow for 2 days. Sterile coverslips were then added to the bottom of each well and the cells were allowed to grow for another 7 days. At this time the media was replaced with $4 \%$ pfa for $30 \mathrm{~min}$, then washed three times with PBS. Coverslips were removed from the plates and immunostaining was completed as outlined above. Images were obtained of intact neurospheres only.

\section{Quantitative real-time PCR}

RT-PCR was performed using first-strand CDNA synthesis system (Invitrogen, USA), according to the manufacturer's instructions. For each RT reaction, $2 \mu \mathrm{g}$ of total RNA was used to synthesize the CDNA. PCR amplification was performed using $1 \mu \mathrm{g}$ of cDNA, one unit of Taq DNA polymerase (Invitrogen), $10 \mathrm{nM}$ of dNTP, and $5 \mathrm{pmol}$ of the following primers in $25 \mu$ total volume: SERCA-S (5'-AGCGCAAGCTGGATGAA TTTG-3'); SERCA-AS (5'-ACATCCTGCAGACAGACATCTG-3'); IP3R-S (5'-AAAGAGGAGCCTCTGTTTGCTG-3'); IP3R-AS (5'-ACATGGCTCTC ATTCTGAGGAAC-3'); GAPDH-S (5'-CACCACCATGGAGAAGGCC-3'); GAPDH-AS (5'-GATGGATGCCTTGGCCAG-3'). Samples were subjected to 40 cycles of PCR amplification. In each cycle denaturing was at $95^{\circ} \mathrm{C}$ for $1 \mathrm{~min}$, annealing at $57^{\circ} \mathrm{C}$ for $1 \mathrm{~min}$, and extension at $72^{\circ} \mathrm{C}$ for $1 \mathrm{~min}$. In total, $20 \mu \mathrm{l}$ aliquots of each PCR product were analyzed on ethidium bromide containing $1 \%$ agarose gels.

Quantitative Real time-PCR was performed using the Mx4000 Multipex Quantitative PCR System (Invitrogen). We used the same method to get cDNA from the SVZ total RNA of four Bax knockout mice and five WT mice. Real-time PCR amplification was performed using $1 \mu \mathrm{g}$ of $\mathrm{CDNA}$, SYBR green supermix, and $5 \mathrm{pmol}$ of the following primers in $25 \mu \mathrm{l}$ total volume: Nestin-S (5'-AAGAATCTTTTCAGATGTGGGAG C-3'); NestinAS (5'-TCCAGCTCTTCGGCAAGGTTGTC-3') and GAPDH-S; GAPDHAS same as above. Samples were subjected to 40 cycles of PCR amplification. In each cycle, denaturing was at $95^{\circ} \mathrm{C}$ for $30 \mathrm{~s}$, annealing at 
$57^{\circ} \mathrm{C}$ for $1 \mathrm{~s}$, and extension at $72^{\circ} \mathrm{C}$ for $1 \mathrm{~s}$. In total, $20 \mu$ aliquots of each PCR product were analyzed on ethidium bromide containing $1 \%$ agarose gels. The plots listed were generated by manufacturer software (Invitrogen).

\section{Western blot analysis}

Mice were anesthetized and perfused with $20 \mathrm{ml}$ ice-cold PBS. The brains were removed and the SVZs dissected on ice. Each sample was homogenized in lysis buffer containing $150 \mathrm{mM} \mathrm{NaCl}, 5 \mathrm{mM}$ Tris- $\mathrm{HCl}$, $0.1 \%$ SDS, $1 \mathrm{mM}$ PMSF, and $1 \%$ NP40 adding one tablet (BMB) to $10 \mathrm{ml}$ lysis buffer. Neural stem cells suspensions were prepared and lysed in lysis buffer. After homogenization, samples were incubated on ice for $15 \mathrm{~min}$ and centrifuged at $16000 \times \mathrm{g}$ at $4^{\circ} \mathrm{C}$ for $20 \mathrm{~min}$. The protein concentration of each lysate was determined by a BCA protein assay kit (PICRCE). In total, $40-100 \mu \mathrm{g}$ protein samples were loaded on a $10 \%$ SDS-PAGE gel, electrophoresed, and transferred onto a Hybond-N membrane. The primary antibody against procasapase-3 (Cell Signaling Technology Inc.), cleaved caspase-3 (Cell Signaling Technology Inc.), SERCA (NOVUS), IP3R (gift of T Tan), or $\alpha$-tubulin (Santa Cruz) was at a dilution of $1: 400$ overnight at $4{ }^{\circ} \mathrm{C}$. Washed membranes were incubated in horseradish peroxidase-conjugated secondary anti-goat antibody for $1 \mathrm{~h}$ at room temperature and immunoblotted protein was detected using ECL (Amersham). Quantitative densitometry was performed using a Kodak image station $2000 \mathrm{R}$ with the ratio of procaspase-3 or cleaved caspase-3 to $\alpha$-tubulin control and compared from three separate sets of neural stem cell cultures.

\section{siRNA preparation and transfection}

The HPLC purified siRNAs were chemically synthesized by Integrated DNA technologies (IDT). The accession numbers given below are from GenBank. The siRNA sequences targeting SERCA (Acc. No. NM_016745) corresponded to the coding regions 1096-1119. The siRNA of $I_{3} R$ (Acc. No. NM_010585) was from position 8150-8170. For annealing of siRNA, the siRNA duplexes were incubated in annealing buffer (100 mM potassium acetate, $30 \mathrm{mM}$ HEPES-KOH at pH 7.4, $2 \mathrm{mM}$ magnesium acetate) for $3 \mathrm{~min}$ at $94^{\circ} \mathrm{C}$. For control RNAi transfection we used oligos specific for green fluorescent protein (GFP) (Dharmacon). ${ }^{53}$

Adult neural stem cells were regularly passaged to maintain exponential growth. At $24 \mathrm{~h}$ prior to transfection, new media was added to the cells. The cells were trypsinized and transferred to six-well plates $\left(5 \times 10^{5}\right.$ cells and $2 \mathrm{ml}$ per well) with fresh media with $20 \mu \mathrm{M}$ of the respective siRNA and $10 \mu \mathrm{g} / \mathrm{ml}$ of Lipofectamine ${ }^{\mathrm{TM}} 2000$, but without bFGF, antibiotics, or FBS. Controls were carried out with Lipofectamine ${ }^{\mathrm{TM}}$ only and Lipofectamine ${ }^{\mathrm{TM}}$ with GFP siRNA. After $72 \mathrm{~h}$, cytosolic $\mathrm{Ca}^{+2}$ release was assessed or cells were lysed for Western blot.

\section{Measurement of cytoplasmic calcium content}

For calcium studies, stem cells passaged 8-10 times were used. The cytoplasmic $\mathrm{Ca}^{+2}$ was measured as the sudden increase in $\left[\mathrm{Ca}^{+2}\right]_{\mathrm{i}}$ on addition of $\mathrm{TG}$ or histamine. $\left[\mathrm{Ca}^{+2}\right]_{\mathrm{i}}$ was measured by the cell permeable fluorescent indicator Fura2-AM. In brief, $3 \times 10^{6}$ cells were washed in $\mathrm{Ca}^{+2}$ free buffer (20 mM HEPES, pH 7.4, $143 \mathrm{mM} \mathrm{NaCl}, 6 \mathrm{mM} \mathrm{KCl}, 1 \mathrm{mM}$ $\mathrm{MgSO}_{4}, 0.1 \%$ glucose, and $250 \mu \mathrm{M}$ sulfinpyrazone) then loaded with $2 \mu \mathrm{M}$ Fura2-AM for $30 \mathrm{~min}$ at $37^{\circ} \mathrm{C}$ in $\mathrm{Ca}^{+2}$ free buffer containing $0.02 \%$ pluronic acid and $0.1 \% \mathrm{BSA}$. After a final wash, cells were resuspended in $\mathrm{Ca}^{+2}$ free buffer and $\left[\mathrm{Ca}^{+2}\right]_{\mathrm{i}}$ was measured as the $340 / 380 \mathrm{~nm}$ excitation wavelength ratio at a $510 \mathrm{~nm}$ wavelength emission (340/380 ratio) in a luminescence spectrophotometer (model LS 50B; Perkin-Elmer). The intracellular calcium concentration was converted from the baseline $340 / 380$ ratio before TG or histamine addition and the peak 340/380 ratio after TG or histamine addition using $K_{d}=225 \mathrm{nM}$ for calcium. ${ }^{54}$

\section{Acknowledgements}

We would like to thank Yuanyuan Chen for her technical assistance and Scott Cameron and Michael Kyba for critical reading of this manuscript. SGK is supported by the Crystal Charity Ball Collaborative Program for Pediatric Brain Injuries and the National Institutes of Health (1K08 HD01470-01). LFP is supported by the Christopher Reeve Paralysis Foundation Consortium on Spinal Cord Injury and by the NINDS.

\section{References}

1. Altman J (1969) Autoradiographic and histological studies of postnatal neurogenesis. IV. Cell proliferation and migration in the anterior forebrain, with special reference to persisting neurogenesis in the olfactory bulb. J. Comp. Neurol. 137: 433-457

2. Kaplan MS and Hinds JW (1977) Neurogenesis in the adult rat: electron microscopic analysis of light radioautographs. Science 197: 1092-1094

3. Alvarez-Buylla A, Garcia-Verdugo JM and Tramontin AD (2001) A unified hypothesis on the lineage of neural stem cells. Nat. Rev. Neurosci. 2: 287-293

4. Alvarez-Buylla A, Seri B and Doetsch F (2002) Identification of neural stem cells in the adult vertebrate brain. Brain Res. Bull. 57: 751-758

5. Lemkine GF, Mantero S, Migne C, Raji A, Goula D, Normandie P, Levi G and Demeneix BA (2002) Preferential transfection of adult mouse neural stem cells and their immediate progeny in vivo with polyethylenimine. Mol. Cell Neurosci. 19: $165-174$

6. Suslov ON, Kukekov VG, Ignatova TN and Steindler DA (2002) Neural stem cell heterogeneity demonstrated by molecular phenotyping of clonal neurospheres. Proc. Natl. Acad. Sci. USA 99: 14506-14511

7. Gage FH (2000) Mammalian neural stem cells. Science 287: 1433-1438

8. McTigue DM, Horner PJ, Stokes BT and Gage FH (1998) Neurotrophin-3 and brain-derived neurotrophic factor induce oligodendrocyte proliferation and myelination of regenerating axons in the contused adult rat spinal cord. J. Neurosci. 18: 5354-5365

9. McTigue DM, Wei P and Stokes BT (2001) Proliferation of ng2-positive cells and altered oligodendrocyte numbers in the contused rat spinal cord. J. Neurosci. 21: 3392-3400

10. Parent JM, Yu TW, Leibowitz RT, Geschwind DH, Sloviter RS and Lowenstein DH (1997) Dentate granule cell neurogenesis is increased by seizures and contributes to aberrant network reorganization in the adult rat hippocampus. J. Neurosci. 17: 3727-3738

11. Johansson CB, Momma S, Clarke DL, Risling M, Lendahl U and Frisen J (1999) Identification of a neural stem cell in the adult mammalian central nervous system. Cell 96: 25-34

12. Kernie SG, Erwin TM and Parada LF (2001) Brain remodeling due to neuronal and astrocytic proliferation after controlled cortical injury in mice. J. Neurosci. Res. 66: 317-326

13. Nakatomi $\mathrm{H}$, Kuriu $\mathrm{T}$, Okabe $\mathrm{S}$, Yamamoto $\mathrm{S}$, Hatano $\mathrm{O}$, Kawahara $\mathrm{N}$, Tamura A, Kirino T and Nakafuku M (2002) Regeneration of hippocampal pyramidal neurons after ischemic brain injury by recruitment of endogenous neural progenitors. Cell 110: 429-441

14. Gross A, McDonnell JM and Korsmeyer SJ (1999) BCL-2 family members and the mitochondria in apoptosis. Genes Dev. 13: 1899-1911

15. Lindsten T, Ross AJ, King A, Zong WX, Rathmell JC, Shiels HA, Ulrich E, Waymire KG, Mahar P, Frauwirth K, Chen Y, Wei M, Eng VM, Adelman DM, Simon MC, Ma A, Golden JA, Evan G, Korsmeyer SJ, MacGregor GR and Thompson CB (2000) The combined functions of proapoptotic Bcl-2 family members bak and bax are essential for normal development of multiple tissues. Mol. Cell 6: 1389-1399 
16. Lindsten T, Golden JA, Zong WX, Minarcik J, Harris MH and Thompson CB (2003) The proapoptotic activities of Bax and Bak limit the size of the neural stem cell pool. J. Neurosci. 23: 11112-11119

17. Beer R, Franz G, Krajewski S, Pike BR, Hayes RL, Reed JC, Wang KK, Klimmer C, Schmutzhard E, Poewe W and Kampfl A (2001) Temporal and spatial profile of caspase 8 expression and proteolysis after experimental traumatic brain injury. J. Neurochem. 78: 862-873

18. Yakovlev AG, Ota K, Wang G, Movsesyan V, Bao WL, Yoshihara K and Faden Al (2001) Differential expression of apoptotic protease-activating factor-1 and caspase-3 genes and susceptibility to apoptosis during brain development and after traumatic brain injury. J. Neurosci. 21: 7439-7446

19. Scorrano L, Oakes SA, Opferman JT, Cheng EH, Sorcinelli MD, Pozzan T and Korsmeyer SJ (2003) BAX and BAK regulation of endoplasmic reticulum $\mathrm{Ca}^{2+}$ : a control point for apoptosis. Science 300: 135-139

20. Lendahl U, Zimmerman LB and McKay RD (1990) CNS stem cells express a new class of intermediate filament protein. Cell 60: 585-595

21. Banerjee A, Roach MC, Wall KA, Lopata MA, Cleveland DW and Luduena RF (1988) A monoclonal antibody against the type II isotype of beta-tubulin. Preparation of isotypically altered tubulin. J. Biol. Chem. 263: 3029-3034

22. Yu TS, Dandekar M, Monteggia LM, Parada LF and Kernie SG (2005) Temporally regulated expression of Cre recombinase in neural stem cells. Genesis 41: 147-153

23. Doetsch $F$ and Alvarez-Buylla A (1996) Network of tangential pathways for neuronal migration in adult mammalian brain. Proc. Natl. Acad. Sci. USA 93 $14895-14900$

24. Jankovski A and Sotelo C (1996) Subventricular zone-olfactory bulb migratory pathway in the adult mouse: cellular composition and specificity as determined by heterochronic and heterotopic transplantation. J. Comp. Neurol. 371: $376-$ 396

25. Reynolds BA, Tetzlaff W and Weiss S (1992) A multipotent EGF-responsive striatal embryonic progenitor cell produces neurons and astrocytes. J. Neurosci. 12: 4565-4574

26. Weiss S, Reynolds BA, Vescovi AL, Morshead C, Craig CG and van der Kooy D (1996) Is there a neural stem cell in the mammalian forebrain? Trends Neurosci. 19: 387-393

27. Song H-J, Stevens CF and Gage FH (2002) Astroglia induce neurogenesis from adult neural stem cells. Nature 417: 39-44

28. Polverino AJ and Patterson SD (1997) Selective activation of caspases during apoptotic induction in HL-60 cells. Effects of a tetrapeptide inhibitor. J. Biol. Chem. 272: 7013-7021

29. Garcia-Calvo M, Peterson EP, Leiting B, Ruel R, Nicholson DW and Thornberry NA (1998) Inhibition of human caspases by peptide-based and macromolecular inhibitors. J. Biol. Chem. 273: 32608-32613

30. Polster BM and Fiskum G (2004) Mitochondrial mechanisms of neural cell apoptosis. J. Neurochem. 90: 1281-1289

31. Zong WX, Li C, Hatzivassiliou G, Lindsten T, Yu QC, Yuan J and Thompson CB (2003) Bax and Bak can localize to the endoplasmic reticulum to initiate apoptosis. J. Cell Biol. 162: 59-69

32. Ferrari D, Pinton P, Szabadkai G, Chami M, Campanella M, Pozzan T and Rizzuto $\mathrm{R}(2002)$ Endoplasmic reticulum, $\mathrm{Bcl}-2$ and $\mathrm{Ca}^{2+}$ handling in apoptosis. Cell Calcium 32: 413-420

33. Bieberich E, MacKinnon S, Silva J, Noggle S and Condie BG (2003) Regulation of cell death in mitotic neural progenitor cells by asymmetric distribution of prostate apoptosis response 4 (PAR-4) and simultaneous elevation of endogenous ceramide. J. Cell Biol. 162: 469-479

34. Kuan CY, Roth KA, Flavell RA and Rakic $P(2000)$ Mechanisms of programmed cell death in the developing brain. Trends Neurosci. 23: 291-297
35. Sommer $L$ and Rao $M(2002)$ Neural stem cells and regulation of cell number. Prog. Neurobiol. 66: 1-18

36. Kuida K, Haydar TF, Kuan CY, Gu Y, Taya C, Karasuyama H, Su MS, Rakic P and Flavell RA (1998) Reduced apoptosis and cytochrome $c$-mediated caspase activation in mice lacking caspase 9. Cell 94: 325-337

37. Pompeiano M, Blaschke AJ, Flavell RA, Srinivasan A and Chun J (2000) Decreased apoptosis in proliferative and postmitotic regions of the Caspase 3 deficient embryonic central nervous system. J. Comp. Neurol. 423: 1-12

38. Roth KA, Kuan C, Haydar TF, D'Sa-Eipper C, Shindler KS, Zheng TS, Kuida K, Flavell RA and Rakic $P$ (2000) Epistatic and independent functions of caspase3 and $\mathrm{Bcl}-\mathrm{X}(\mathrm{L})$ in developmental programmed cell death. Proc. Natl. Acad. Sci. USA 97: 466-471

39. Cecconi F, Alvarez-Bolado G, Meyer BI, Roth KA and Gruss P (1998) Apaf1 (CED-4 homolog) regulates programmed cell death in mammalian development. Cell 94: 727-737

40. Yoshida H, Kong YY, Yoshida R, Elia AJ, Hakem A, Hakem R, Penninger JM and Mak TW (1998) Apaf1 is required for mitochondrial pathways of apoptosis and brain development. Cell 94: 739-750

41. D'Sa-Eipper $C$ and Roth KA (2000) Caspase regulation of neuronal progenitor cell apoptosis. Dev. Neurosci. 22: 116-124

42. Berridge MJ, Lipp P and Bootman MD (2000) The versatility and universality of calcium signalling. Nat. Rev. Mol. Cell. Biol. 1: 11-21

43. Ma TS, Mann DL, Lee JH and Gallinghouse GJ (1999) SR compartment calcium and cell apoptosis in SERCA overexpression. Cell Calcium 26: 25-36

44. Bian X, Hughes Jr FM, Huang Y, Cidlowski JA and Putney Jr JW (1997) Roles of cytoplasmic $\mathrm{Ca}^{2+}$ and intracellular $\mathrm{Ca}^{2+}$ stores in induction and suppression of apoptosis in S49 cells. Am. J. Physiol. 272 (Part 1): C1241-1249

45. Pinton $P$, Ferrari $D$, Magalhaes $P$, Schulze-Osthoff $K$, Di Virgilio F, Pozzan $T$ and Rizzuto R (2000) Reduced loading of intracellular $\mathrm{Ca}(2+)$ stores and downregulation of capacitative $\mathrm{Ca}(2+)$ influx in Bcl-2-overexpressing cells. J. Cell Biol. 148: 857-862

46. Demaurex $N$ and Distelhorst $C$ (2003) Cell biology. Apoptosis - the calcium connection. Science 300: 65-67

47. Oakes SA, Scorrano L, Opferman JT, Bassik MC, Nishino M, Pozzan T and Korsmeyer SJ (2005) Proapoptotic BAX and BAK regulate the type 1 inositol trisphosphate receptor and calcium leak from the endoplasmic reticulum. Proc. Natl. Acad. Sci. USA 102: 105-110

48. Fall CP and Keizer JE (2001) Mitochondrial modulation of intracellular $\mathrm{Ca}(2+)$ signaling. J. Theor. Biol. 210: 151-165

49. Deng $Y$, Lin $Y$ and $W u X$ (2002) TRAIL-induced apoptosis requires Baxdependent mitochondrial release of Smac/DIABLO. Genes Dev. 16: 33-45

50. Boehning D, Patterson RL, Sedaghat L, Glebova NO, Kurosaki T and Snyder SH (2003) Cytochrome $c$ binds to inositol $(1,4,5)$ trisphosphate receptors, amplifying calcium-dependent apoptosis. Nat. Cell Biol. 5: 1051-1061

51. Knudson CM, Tung KS, Tourtellotte WG, Brown GA and Korsmeyer SJ (1995) Bax-deficient mice with lymphoid hyperplasia and male germ cell death. Science 270: 96-99

52. McCarthy NJ, Whyte MK, Gilbert CS and Evan Gl (1997) Inhibition of Ced-3/ ICE-related proteases does not prevent cell death induced by oncogenes, DNA damage, or the Bcl-2 homologue Bak. J. Cell Biol. 136: 215-227

53. Novina CD, Murray MF, Dykxhoorn DM, Beresford PJ, Riess J, Lee SK, Collman RG, Lieberman J, Shankar P and Sharp PA (2002) siRNA-directed inhibition of HIV-1 infection. Nat. Med. 8: 681-686

54. Grynkiewicz G, Poenie M and Tsien RY (1985) A new generation of $\mathrm{Ca}^{2+}$ indicators with greatly improved fluorescence properties. J. Biol. Chem. 260: $3440-3450$ 